\title{
Assessment of Reservoir Water Quality Using Water Quality Indices: A Case Study from Jordan.
}

\author{
Mahmoud M. Abualhaija ${ }^{\mathrm{a}}$, Ahmad H. Abu Hilal ${ }^{\mathrm{b}}$, Maisa'a W. Shammout ${ }^{\mathrm{c}}$ and Alsharifa-Hind Mohammad ${ }^{\mathrm{d}}$. \\ ${ }^{a, c, d}$ Water, Energy and Environment Center, The University of Jordan, Amman -Jordan. \\ ${ }^{b}$ Faculty of Marine Sciences, The University of Jordan, Aqaba Branch -Jordan \\ * Corresponding Author-Dr. Mahmoud M. Abualhaija.
}

ORCID ID: 0000-0002-4341-5308.

\begin{abstract}
This study was conducted to evaluate the water quality of King Talal Dam (KTD) in Jordan and its suitability for irrigation purposes based on the measurements of several physicochemical parameters and water quality indices. Surface water was sampled from seven different locations in the dam. The values of electrical conductivity (EC) and total dissolved solids (TDS) indicate that KTD surface water is relatively saline but still falls within the permissible category for irrigation. The dam's water is suitable for irrigation based on the sodium adsorption ratio-(SAR) and magnesium hazard(MH) data. It lies between permissible to doubtful categories with respect to the results of sodium percentage $(\mathrm{Na} \%)$ and lies within the marginal category for irrigation based on Kelly's ratio-(KR) values. Therefore, crops that are not sensitive to sodium and soils with light textures and good permeability are recommended. The data of irrigation water quality index (IWQI) showed that KTD water distributed between moderate to high restrictions for irrigation uses, which indicates that the dam's water can be used to irrigate plants with moderate to high salt tolerance and in soils with moderate to high permeability and good leaching of salts. KTD water requires special measures to reduce salinity and sodium hazards.
\end{abstract}

Keywords: King Talal Dam-Jordan; Physicochemical parameters; Reservoir water quality; Water quality index; Irrigation.

\section{INTRODUCTION}

Jordan is one of the most water-stressed countries in the world. Water per capita in Jordan is around 150 cubic meters per year, which is much less than the minimum water per capita in the severe water-scarce countries (500 cubic meters per year) [1]. The problem of water scarcity is increasing with time due to several factors such as climate change, rapid population growth, high social and economic development, growing increase in water demand, and lack of water management [2]. Water sources in Jordan are divided into conventional and non-conventional; these sources are depending on rainwater, which is variable and fluctuates spatially and temporally. The conventional sources (surface and groundwater) are the major available sources for all purposes (drinking, agriculture, and industry), whereas nonconventional sources such as treated wastewater are available only for agriculture and industry [2].
Jordan faces many challenges to meet the domestic, industrial and agricultural water needs due to the continuous increase in population growth, dramatic increase in the number of refugees from neighboring countries, especially Syria and Iraq, overuse of water resources as a result of growing water demand and increased agricultural uses (e.g. fertilizers and pesticides), in addition to the dumping of domestic and industrial wastes into the water resources. All these factors led to changes in chemical, physical and biological characteristics of surface and groundwater and deteriorate their quality [2-4].

Chemical and physical characteristics of surface water (e.g. lakes and reservoirs) depend on several factors such as climate changes, geochemistry, and geomorphology of the area that surrounded the water bodies. Generally speaking, the pollution of surface water comes from two main sources; point sources and non-point sources [5]. The non-point sources (diffuse sources), such as anthropogenic activities, atmospheric depositions, automobile exhausts, urban runoff, pesticides and fertilizer applications in agriculture, while the point include discharges from industrial and domestic wastewater plants [6].

The suitability of surface water for irrigation is mainly based on the dissolved substances. One of these substances is the dissolved salts, which should comprise relatively small quantities of dissolved solids to maintain good water quality for irrigation, thus provides higher productivity of the soil-crop. Salinity and sodicity of surface waters play an important role in the propriety of these waters for irrigation. Increasing the amount of the dissolved salts in irrigation water affects the permeability and aeration of the soil, and increases the osmotic pressure, which reduces the availability of water for plant growth, thus affects the soil productivity [7].

The main objective of this study is to assess the water quality of King Talal dam the largest man-made water body in Jordan and check its suitability for agricultural irrigation. Accordingly, several physicochemical parameters were measured, including temperature, $\mathrm{pH}$, electrical conductivity (EC), total dissolved solids (TDS), calcium $\left(\mathrm{Ca}^{2+}\right)$, magnesium $\left(\mathrm{Mg}^{2+}\right)$, sodium $\left(\mathrm{Na}^{+}\right)$, potassium $\left(\mathrm{K}^{+}\right)$, bicarbonate $\left(\mathrm{HCO}_{3}{ }^{-}\right)$and chloride $\left(\mathrm{Cl}^{-}\right)$. The quality of the dam's water for irrigation purposes was evaluated based on different water quality indices, including irrigation water quality index (IWQI), sodium adsorption ratio (SAR) electrical conductivity (EC), sodium percentage (Na \%), magnesium hazard (MH) and Kelly's ratio (KR). 


\section{DESCRIPTION OF THE STUDY AREA}

King Talal Dam (KTD) is one of the largest surface water bodies in Jordan; it was constructed in 1978, with a height of 90 meters, and a storage capacity of 57 million cubic meters (MCM). In a second stage between (1983-1986), the height of the dam was raised to increase the reservoir capacity to 85 million cubic meters in order to meet the increased water demands [8]. The dam was constructed within the Zarqa River basin with an estimated catchment area of $3400 \mathrm{~km}^{2}$. The dam was previously used to supply water for municipal use in Amman (Capital of Jordan) region, but due to the high pollution levels in the dam, its water is used now for irrigation in the Jordan Valley [9-11].

Zarqa River and Wadi Rmemeen are the main two sources of water in KTD. Zarqa River is one of the largest rivers in the country, where the water discharges in the river come from natural runoff, major springs and the effluents from Al-Samra wastewater treatment plant (WWTP), which is the largest wastewater treatment plant in Jordan. Wadi Rmemeen is the second source of water in KTD and composed of the effluents from Al-Baqa'a WWTP and some water springs. Wastewater treatment plants (WWTPs) in the Zarqa basin contribute about more than $50 \%$ of the water effluent entering $\operatorname{KTD}[8,9,12]$. In addition to the effluents of WWTPs, other sources of pollution that directly or indirectly affect the water quality of the dam include industrial wastewater discharges, reaching the dam via Zarqa River; urban activities including cesspools, runoff, and transportation; agricultural runoff; and leachate from landfills [11, 13-15].

\section{METHODOLOGY}

Surface water for physical and chemical analyses was sampled during spring 2016 from seven locations (sampling sites) along the main body of King Talal Dam (Fig. 1): site 1 and site 2 in the eastern part of the dam near the entrance of the dam and close to the flowing point of the Zarqa River into the dam. Sites 3 and 4 are in the middle of the dam. Site 5 is located in the southern part of the dam near the Wadi Rmemeen tributary. Site 6 was selected near the end of the dam and site 7 in the western part at the end of the dam. Highdensity polyethylene (HDPE) bottles were used to collect water samples. The bottles were rinsed three times with the water of each sampling site before collection. Immediately after sampling, the bottles were kept at $4{ }^{\circ} \mathrm{C}$ in an icebox and then transported to be analyzed in the laboratory.

Surface water samples were analyzed for different physical and chemical parameters including temperature, $\mathrm{pH}, \mathrm{EC}$, TDS, cations $\left(\mathrm{Ca}^{2+}, \mathrm{Mg}^{2+}, \mathrm{Na}^{+}\right.$and $\left.\mathrm{K}^{+}\right)$, anions $\left(\mathrm{HCO}_{3}{ }^{-}\right.$and $\mathrm{Cl}^{-}$ ). In situ measurements of temperature, $\mathrm{pH}, \mathrm{EC}$, and TDS were measured using calibrated portable meters. The concentrations of cations and anions were determined at the laboratory according to the Standard Methods [16].

\section{RESULTS AND DISCUSSION}

\subsection{Temperature and $\mathbf{p H}$}

The mean values of temperature in the surface water of KTD (Table 1) varied between 24.7 to $26.2{ }^{\circ} \mathrm{C}$ with an average value of $25.4{ }^{\circ} \mathrm{C}$. Whereas, the mean values of $\mathrm{pH}$ ranged between 7.86 and 8.26 with an average value of 8.03 , which indicates that the surface water of KTD is weakly alkaline and the important major anion; the bicarbonate is present in the water. During the early spring, the temperature and photosynthetic activity increase, the concentration of carbon dioxide decrease and the growth of phytoplankton begin to increase, which increases the $\mathrm{pH}$ value of the water. The lowest $\mathrm{pH}$ values were recorded in the eastern part of KTD near the Zarqa River which can be attributed to the industrial and wastewater discharges that reach the dam from the river $[17,18]$.

The $\mathrm{pH}$ values in the current study are within the Food and Agriculture Organization (FAO) recommended $\mathrm{pH}$ range (6.58.4) for irrigation water [19] and within the Jordanian permissible limit for the use of reclaimed water for irrigation purposes [20] (Table 2).

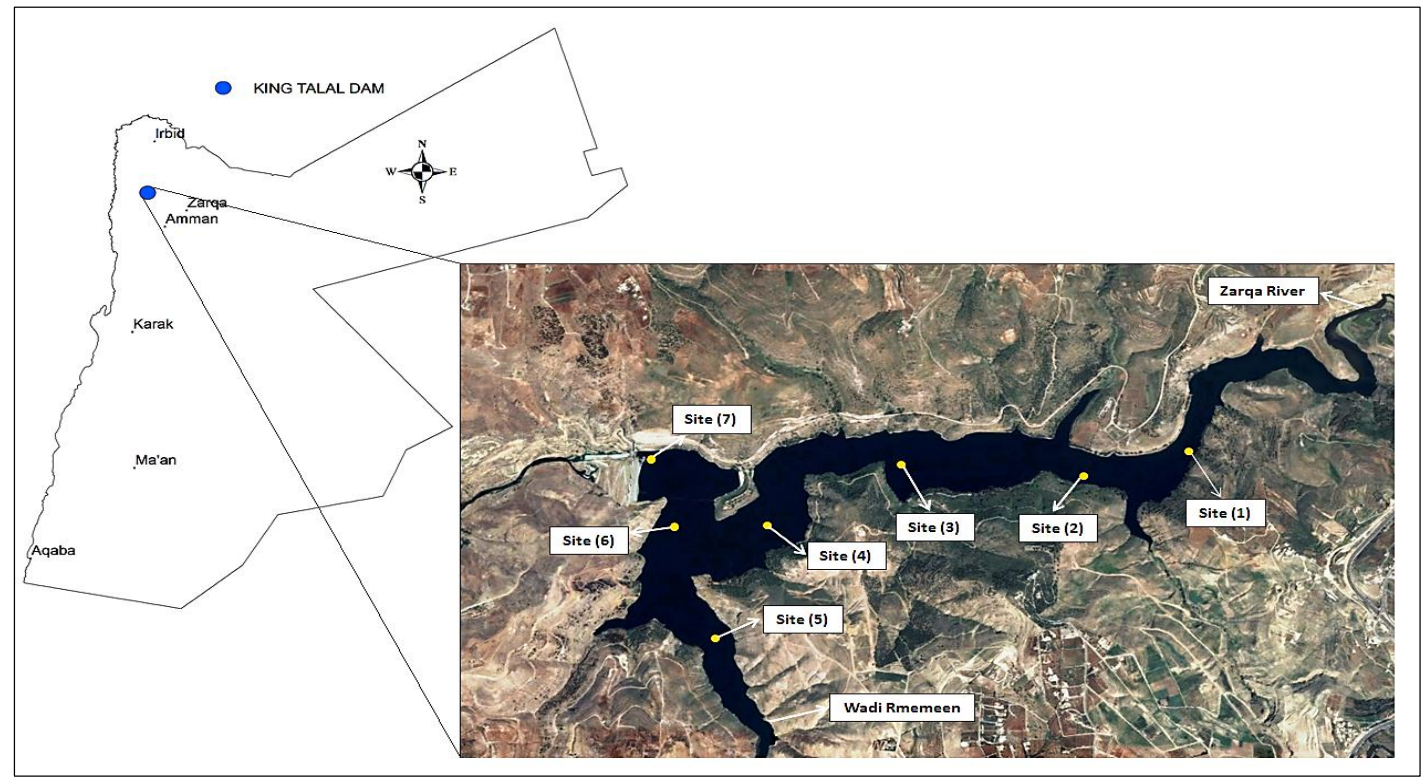

Fig. 1 Location map of water sampling sites in King Talal Dam-Jordan 
International Journal of Engineering Research and Technology. ISSN 0974-3154, Volume 13, Number 3 (2020), pp. $397-406$

(C) International Research Publication House. https://dx.doi.org/10.37624/IJERT/13.3.2020.397-406

Table 1. Results of analyses of water collected from King Talal Dam

\begin{tabular}{|c|c|c|c|c|c|c|c|c|c|c|}
\hline Site & $\begin{array}{l}\mathrm{pH} \\
\mathrm{SU}\end{array}$ & Temp. ${ }^{\circ} \mathrm{C}$ & $\mathrm{EC} \mu \mathrm{s} / \mathrm{cm}$ & TDS mg/l & $\mathrm{Ca}^{2+} \mathrm{mg} / \mathrm{l}$ & $\mathrm{Mg}^{2+} \mathrm{mg} / \mathrm{l}$ & $\mathrm{Na}^{+} \mathrm{mg} / \mathrm{l}$ & $\begin{array}{c}\mathrm{K}^{+} \\
\mathrm{mg} / \mathrm{l}\end{array}$ & $\begin{array}{c}\mathrm{HCO}_{3}^{-} \\
\mathrm{mg} / \mathrm{l}\end{array}$ & $\mathrm{Cl}^{-} \mathrm{mg} / \mathrm{l}$ \\
\hline Site 1 & 7.86 & 24.7 & 1909.9 & 1222.3 & 99.2 & 33.7 & 248.0 & 34.9 & 150.6 & 356.2 \\
\hline Site 2 & 7.90 & 25.3 & 1828.4 & 1170.2 & 96.5 & 33.3 & 239.7 & 33.8 & 143.8 & 347.3 \\
\hline Site 3 & 7.87 & 25.6 & 1675.8 & 1072.6 & 91.3 & 30.8 & 232.0 & 32.3 & 153.0 & 342.8 \\
\hline Site 4 & 8.02 & 25.1 & 1579.6 & 1015.3 & 87.0 & 29.6 & 228.7 & 29.6 & 144.0 & 339.1 \\
\hline Site 5 & 8.11 & 25.2 & 1650.3 & 1056.2 & 93.7 & 32.0 & 219.0 & 28.9 & 168.0 & 325.2 \\
\hline Site 6 & 8.17 & 25.5 & 1490.0 & 0953.6 & 87.3 & 30.5 & 214.4 & 28.4 & 150.4 & 319.6 \\
\hline Site 7 & 8.26 & 26.2 & 1375.6 & 0880.4 & 75.3 & 24.8 & 206.3 & 27.8 & 137.8 & 296.4 \\
\hline Min & 7.86 & 24.7 & 1375.6 & 0880.4 & 75.3 & 24.8 & 206.3 & 27.8 & 137.8 & 296.4 \\
\hline Max & 8.26 & 26.2 & 1909.9 & 1222.3 & 99.2 & 33.7 & 248.0 & 34.9 & 168.0 & 356.2 \\
\hline Mean & 8.03 & 25.4 & 1644.2 & 1052.9 & 90.0 & 30.7 & 226.9 & 30.8 & 149.7 & 332.4 \\
\hline
\end{tabular}

Table 2. Comparison of the results of the present study with FAO recommended concentrations for irrigation quality and Jordanian allowable limits for the use of reclaimed water for irrigation purposes (2006)

\begin{tabular}{|c|c|c|c|c|c|c|}
\hline \multirow[t]{2}{*}{ Parameter } & \multicolumn{2}{|c|}{ This Study } & \multicolumn{2}{|c|}{$\begin{array}{l}\text { Jordanian Allowable Limits } \\
\qquad(\mathrm{mg} / \mathrm{l})[20]\end{array}$} & \multicolumn{2}{|c|}{$\begin{array}{c}\text { FAO guidelines } \\
\text { [19] }\end{array}$} \\
\hline & Ranges & Units & Ranges & Units & Ranges & Units \\
\hline $\mathrm{pH}$ & $7.86-8.26$ & $\mathrm{SU}$ & $6.0-9.0$ & SU & $6.5-8.4$ & $\mathrm{SU}$ \\
\hline TDS & $880.4-1222.3$ & $\mathrm{mg} / \mathrm{l}$ & $0-1500$ & $\mathrm{mg} / \mathrm{l}$ & $0-2000$ & $\mathrm{mg} / \mathrm{l}$ \\
\hline $\mathrm{EC}$ & $1375.6-1909.9$ & $\mu \mathrm{s} / \mathrm{cm}$ & --- & $\mu \mathrm{s} / \mathrm{cm}$ & $0-3000$ & $\mu \mathrm{s} / \mathrm{cm}$ \\
\hline $\mathrm{Ca}$ & $75.3-99.2$ & $\mathrm{mg} / \mathrm{l}$ & $0-230$ & $\mathrm{mg} / \mathrm{l}$ & $0-20$ & $\mathrm{meq} / \mathrm{l}$ \\
\hline $\mathrm{Mg}$ & $24.8-33.7$ & $\mathrm{mg} / \mathrm{l}$ & $0-100$ & $\mathrm{mg} / \mathrm{l}$ & $0-5$ & $\mathrm{meq} / \mathrm{l}$ \\
\hline $\mathrm{Na}$ & $206.3-248.0$ & $\mathrm{mg} / \mathrm{l}$ & $0-230$ & $\mathrm{mg} / \mathrm{l}$ & $0-40$ & $\mathrm{meq} / \mathrm{l}$ \\
\hline $\mathrm{K}$ & $27.8-34.9$ & $\mathrm{mg} / \mathrm{l}$ & --- & $\mathrm{mg} / \mathrm{l}$ & --- & $\mathrm{meq} / 1$ \\
\hline $\mathrm{HCO} 3$ & $137.8-168.0$ & $\mathrm{mg} / \mathrm{l}$ & $0-400$ & $\mathrm{mg} / 1$ & $0-10$ & $\mathrm{meq} / 1$ \\
\hline $\mathrm{Cl}$ & $296.4-356.2$ & $\mathrm{mg} / \mathrm{l}$ & $0-400$ & $\mathrm{mg} / \mathrm{l}$ & $0-30$ & $\mathrm{meq} / \mathrm{l}$ \\
\hline SAR & $4.98-5.49$ & --- & $0-9.0$ & --- & $0-9.0$ & --- \\
\hline
\end{tabular}

\subsection{Cations}

The mean concentrations of $\mathrm{Ca}^{2+}, \mathrm{Mg}^{2+}, \mathrm{Na}^{+}$and $\mathrm{K}^{+}$ranged between 75.3-99.2, 24.8-33.7, 206.3-248.0, 27.8-34.9 mg/l, respectively, with a mean concentration of 90.0, 30.7, 226.9 and $30.8 \mathrm{mg} / \mathrm{l}$, respectively (Table 1 ). The maximum mean concentrations of the major cations $\left(\mathrm{Ca}^{2+}, \mathrm{Mg}^{2+}, \mathrm{Na}^{+}\right.$and $\left.\mathrm{K}^{+}\right)$ were recorded in the sites near the Zarqa river (sites 1 and 2), whereas the lowest mean concentrations were recorded in the surface water at the far end of the dam (site 7). However, the concentrations of $\mathrm{Ca}^{2+}$ and $\mathrm{Mg}^{2+}$ were tending to increase slightly in the surface water near the Wadi Rmemeen flowing point into the dam (site 5).

Major cations in water are mainly affected by the nature of the geology of the catchment area and the weathering processes that affect rocks and soils [21]. The concentrations of major elements in water may also be increased by the discharge from wastewater treatment plants. Other sources of major elements are the discharges from industry and drainage water from agricultural lands [22]. The distribution of major cations in this study showed a more or less similar trend, which indicates that the factors affecting their occurrence and distribution are the same, and include the discharges that enter KTD via Zarqa River and Wadi Rmemeen.

The concentrations of all major cations in the present study lie within the FAO permissible ranges for irrigation water [19] and within the Jordanian permissible limits [20] except for $\mathrm{Na}$ concentrations in sites 1,2 , and 3 , which were slightly higher than the Jordanian limits (Table 2).

\subsection{Anions}

\subsubsection{Bicarbonate $\left(\mathrm{HCO}_{3}^{-}\right)$}

The carbonate species $\left(\mathrm{HCO}_{3}{ }^{-}\right.$and $\left.\mathrm{CO}_{3}{ }^{2-}\right)$ in surface and groundwater contribute to the total alkalinity; their ratios rely on the hydrogen activity and temperature [23]. The sources of bicarbonate and carbonate in surface water come from atmospheric deposition, biological respiration as well as the weathering of rock, particularly from the carbonate rocks. In dry conditions, high concentrations of carbonate and bicarbonate are precipitated in the form of calcium carbonate 
and magnesium carbonate, thus decreasing the concentration of calcium and magnesium relative to the concentration of sodium [23, 24].

The results in (Table 1) showed variations in the distribution of bicarbonate in surface water of KTD. The highest mean concentration of bicarbonate $(168 \mathrm{mg} / \mathrm{l})$ was recorded in site 5 , which can be attributed to the effluents from the Wadi Rmemeen tributary [17]. The lowest mean concentration of bicarbonate $(137.8 \mathrm{mg} / \mathrm{l})$ was recorded in surface water of site 7 at the outlet point of the dam. The bicarbonate distribution in this study is similar to the distribution that has been published by Al-Taani et al. (2018), who found horizontal variations of bicarbonate in surface water of KTD and suggested that the precipitation of $\mathrm{CaCO}_{3}$ explains the relatively lower concentrations of the bicarbonate in surface water near the end of the dam. However, Table (2) showed that the concentrations of bicarbonate in surface water of KTD are within the Jordanian standards for the use of reclaimed water for irrigation purposes [20] and within the FAO standards for irrigation water [19].

\subsubsection{Chlorides $\left(\mathrm{Cl}^{-}\right)$}

Chloride is an important anion (component) in irrigation water, it is essential to plants, but in very low concentration, where it can be toxic and hazardous at a high concentration because it cannot be adsorbed by soil, easily moves in soil solution and taken up by the plants and accumulate in the leaves [19].

The results in (Table 1) showed that chlorides concentrations in the surface water of KTD ranged between 296.4 and 356.2 $\mathrm{mg} / \mathrm{l}$ with a mean value of $332.4 \mathrm{mg} / \mathrm{l}$. Higher mean concentrations of chlorides were recorded in sites (1 and 2) where the water of Zarqa River tributary enters into the dam, compared to those recorded in site (7) at the dam's outlet. Chlorides enter the surface water from several sources, including rocks containing chlorides, agricultural runoff and wastewaters from industrial, and wastewater treatment plants [25]. Accordingly, the high chlorides concentrations during the spring season in the sites near the entrance of the dam can be attributed to wastewater effluents from industrial and wastewater treatment plants that reaching the dam via Zarqa River.

According to the data in (Table 2), the concentrations of chlorides in the present study are within the Jordanian [20] and FAO [19] standards for irrigation water.

\subsection{Salinity}

The salinity of water can be identified based on total dissolved solids (TDS) or electrical conductivity (EC). TDS is the total amount of dissolved substances in the water, which includes inorganic salts in addition to a small amount of organic matter. The most common inorganic salts in water are $\mathrm{Ca}^{2+}$, $\mathrm{Mg}^{2+}, \mathrm{Na}^{+}$, and $\mathrm{K}^{+}$, which defined as major cations and $\mathrm{HCO}_{3}{ }^{-}, \mathrm{Cl}^{-}$and $\mathrm{SO}_{4}{ }^{2-}$ defined as major anions.

Electrical conductivity (EC) is one of the important parameters to assess the quality of surface and groundwater. It is defined as the capacity of water to transfer electrical flow. EC is directly related to the amount of TDS and major ions in water, where the more TDS and major ions present, the higher water conductivity.

$\mathrm{EC}$ value in water is affected by temperature and $\mathrm{pH}$ changes as well as chemical reactions and physical changes in water. Elevated salinity in irrigation water causes a high osmotic potential, where the salts in solution and in the soil are competing with the plants for the available water. Therefore, the salts will increase in the soil and result in a drought condition [19, 26, 27]. The possible sources of dissolved solids in surface water are from weathering and erosion of rocks, urban and agricultural runoff, and industrial and wastewater discharges [28].

Table (1) showed that the TDS values in the present study varied between 880.4 and $1222.3(\mathrm{mg} / \mathrm{l})$, with a mean value of $1052.9(\mathrm{mg} / \mathrm{l})$, Whereas, the EC values ranged between 1375.6 and $1909.9(\mu \mathrm{s} / \mathrm{cm})$, with a mean concentration of $1644.2(\mu \mathrm{s} / \mathrm{cm})$.

According to the classifications of USDA salinity laboratory for irrigation water based on EC and TDS values [29] (Table 3 ), all samples collected from the KTD surface water are lying within the permissible category (C3: high salinity water) for irrigation. Water in the permissible category (C3) is likely to damage the crops with low salinity tolerance even with good drainage soils. Therefore, excess irrigation for leaching or periodic use of low salinity water and good drainage are needed to improve the plant's growth [19].

The values of TDS and EC in the present study are within the Jordanian allowable limits for the use of reclaimed water for irrigation purposes [20] and within the FAO standards for irrigation [19] (Table 2).

\subsection{Sodium Adsorption Ratio (SAR)}

Sodium adsorption ratio (SAR) is the ratio of sodium ion to calcium and magnesium ions in a water sample, where calcium and magnesium ions reduce the effect of sodium on the soil. SAR is an important extensively used parameter to determine the suitability of water for irrigation, which evaluates the sodium adsorption rate by the soil. SAR is also termed as sodium hazard or sodicity hazard. Irrigation water with high sodium content is particularly important because of the destructive effect of sodium on the soil structure by reducing water movement and the soil infiltration rate due to soil dispersion thereby affecting plant growth [30].

SAR was computed based on the following Equation [29].

$$
\mathbf{S A R}=\frac{\mathbf{N a}}{\sqrt{(\mathbf{C a}+\mathbf{M g}) / \mathbf{2}}} \text { (ions units in meq/liter) }
$$

SAR values in the surface water of KTD (Table 4) varied between 4.98 and 5.49, with an average value of 5.27. The classifications of irrigation water based on the SAR values [29] (Table 5) showed that the collected surface water samples from the KTD fall in (S1) category and indicate excellent quality for irrigation. The water in this category is with low sodium hazard and suitable for all types of soils and all types 
International Journal of Engineering Research and Technology. ISSN 0974-3154, Volume 13, Number 3 (2020), pp. $397-406$

(C) International Research Publication House. https://dx.doi.org/10.37624/IJERT/13.3.2020.397-406

of crops except for crops that are highly sensitive to sodium.

Table 3. USDA salinity laboratory classifications of irrigation water based on EC and TDS values [29]

\begin{tabular}{|c|l|l|l|}
\hline Water Class & Water Quality & EC $(\mu \mathrm{s} / \mathrm{cm})$ & $\mathrm{TDS} \mathrm{mg} / \mathrm{l}$ \\
\hline C1 & Low-Salinity Water (Excellent for Irrigation) & $<250$ & $<150$ \\
\hline C2 & Medium-Salinity Water (Good for Irrigation) & $250-750$ & $150-500$ \\
\hline C3 & High-Salinity Water (Permissible for Irrigation) & $750-2250$ & $500-1500$ \\
\hline C4 & Very High-Salinity Water (Unsuitable for Irrigation) & $>2250$ & $>1500$ \\
\hline
\end{tabular}

Table 4. Water quality results for the collected water samples from King Talal Dam

\begin{tabular}{|c|c|c|c|c|c|}
\hline Site & SAR meq/l & EC $\mu \mathrm{s} / \mathrm{cm}$ & $\mathrm{Na} \%$ & Mg Hazard & Kelly's Ratio \\
\hline Site 1 & 5.49 & 1909.9 & 60.2 & 35.9 & 1.40 \\
\hline Site 2 & 5.37 & 1828.4 & 59.9 & 36.3 & 1.38 \\
\hline Site 3 & 5.36 & 1675.8 & 60.6 & 35.7 & 1.42 \\
\hline Site 4 & 5.40 & 1579.6 & 61.2 & 35.9 & 1.47 \\
\hline Site 5 & 4.98 & 1650.3 & 58.4 & 36.0 & 1.30 \\
\hline Site 6 & 5.03 & 1490.0 & 59.4 & 36.6 & 1.36 \\
\hline Site 7 & 5.27 & 1375.6 & 62.5 & 35.2 & 1.55 \\
\hline Min & 4.98 & 1375.6 & 58.4 & 35.2 & 1.30 \\
\hline Max & 5.49 & 1909.9 & 62.5 & 36.6 & 1.55 \\
\hline Mean & 5.27 & 1644.2 & 60.3 & 36.0 & 1.41 \\
\hline
\end{tabular}

Table 5. Classification of irrigation water based on SAR values [29]

\begin{tabular}{|l|l|l|}
\hline Water Class & Water Quality & SAR \\
\hline S1 & Low Sodium hazard (Excellent for Irrigation) & $0-10$ \\
\hline S2 & Medium Sodium hazard (Good for Irrigation) & $10-18$ \\
\hline S3 & High Sodium hazard (Permissible for Irrigation) & $18-26$ \\
\hline S4 & Very High Sodium hazard (Unsuitable for Irrigation) & $>26$ \\
\hline
\end{tabular}

\subsection{Sodium Percentage (Na \%)}

The Sodium percentage $(\mathrm{Na} \%)$ is one of the water quality parameters used to determine the suitability of water for irrigation, $\mathrm{Na} \%$ was calculated using the following equation [31] and expressed in meq/l:

$$
\mathbf{N a} \%=\frac{(\mathbf{N a}+\mathbf{K})}{(\mathbf{N a}+\mathbf{C a}+\mathbf{M g}+\mathbf{K})} \times \mathbf{1 0 0} \text { (ions units meq/liter) }
$$

Based on the data in (Table 4), the values of $\mathrm{Na} \%$ in the surface water of KTD range between 58.4 and 62.5, with an average value of 60.3 . According to the classifications of irrigation water based on $\mathrm{Na} \%$ [31, 32] (Table 6), the collected samples in the current study distributed between permissible to doubtful categories for irrigation, where $43 \%$ of the samples fall under the category of permissible for irrigation and $57 \%$ under the doubtful category for irrigation.
Table 6. Classifications of irrigation water based on $\mathrm{Na} \%$ values $[31,32]$

\begin{tabular}{|l|l|}
\hline Water Quality & $\mathrm{Na} \%$ \\
\hline Excellent for Irrigation & $<20$ \\
\hline Good for Irrigation & $20-40$ \\
\hline Permissible for Irrigation & $40-60$ \\
\hline Doubtful for Irrigation & $60-80$ \\
\hline Unsuitable for Irrigation & $>80$ \\
\hline
\end{tabular}

\subsection{U.S. Salinity Laboratory's diagram for the} classification of irrigation waters [29].

The U.S. Salinity Laboratory's (USSL) (1954) developed a diagram to determine the viability of water for irrigation purposes based on the values of the electrical conductivity and the sodium adsorption ratio, USSL diagram is also known as 


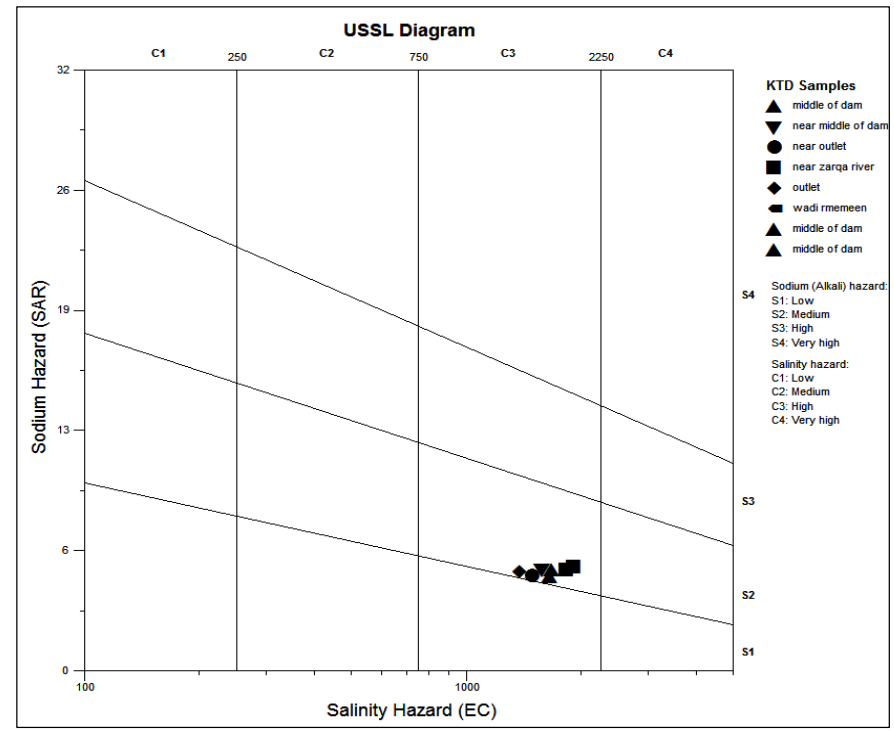

Fig. 2 USSL diagram of the collected surface water samples from KTD (using Aquachem program version 4.0)

Wilcox diagram. Simply, the diagram is a plot of salinity hazard (EC) on the $\mathrm{X}$-axis versus the sodium or sodicity hazard (SAR) on the Y-Axis. USSL diagram (Fig. 2) classifying the waters into four types on the basis of salinity hazard [29]: C1 (low salinity hazard), C2 (medium salinity hazard), C3 (high salinity hazard), and C4 (very high salinity hazard) (EC), and into four types on the basis of sodium hazard (SAR): S1 (low sodium hazard), S2 (medium sodium hazard), S3 (high sodium hazard), and S4 (very high sodium hazard).

The USSL diagram (Fig. 2) showed that all the collected samples from the surface water of KTD belong to the category of moderate water quality for irrigation (C3S2), where the water of this category is with high salinity hazard and medium sodium hazard. Accordingly, it is suggested that the water of KTD needs a kind of treatment to reduce salinity and sodium hazards. However, with its present qualities, it can be used to irrigate crops with good salt-tolerance and soils with good drainage. Therefore, the soils with restricted leaching conditions and crops with low salt-tolerance are not suitable and not recommended.

\subsection{Magnesium Hazard (MH)}

The elevated concentrations of magnesium in irrigation waters will unfavorably affect the quality of the soil and changing it to alkali soil and reduce crop production [19]. Magnesium hazard $(\mathrm{MH})$ or magnesium ratio (MR) can be calculated using the following equation [33].

$$
\mathbf{M H}=\frac{(\mathbf{M g}) \times \mathbf{1 0 0}}{(\mathbf{C a}+\mathbf{M g})} \quad \text { (ions units meq/liter) }
$$

If the value of $\mathrm{MH}$ is less than 50, the water is suitable for irrigation, while the water is considered unsuitable for irrigation when the value of MH is greater than 50 . The results in (Table 4) indicated that the $\mathrm{MH}$ values in the present study ranged between 35.2 and 36.6, with a mean value of 36 . Consequently, the water of KTD is suitable for irrigation and can be used safely.

\subsection{Kelley's Ratio (KR)}

Water can be classified for irrigation based on Kelley's ratio (KR), where $\mathrm{KR}$ measures the $\mathrm{Na}$ concentration against the concentrations of $\mathrm{Ca}$ and $\mathrm{Mg}$ [34].

$$
\mathbf{K R}=\frac{\mathbf{N a}}{(\mathbf{C a}+\mathbf{M g})} \quad \text { (ions units meq/liter) }
$$

If the $\mathrm{KR}$ value is more than 1 indicates an excess concentration of $\mathrm{Na}$ in water, where the elevated concentrations of $\mathrm{Na}$ in irrigation water can adversely affect the soil structure and features and reducing permeability [35]. The water is considered safe and suitable for irrigation with the KR value of less than 1 . When the KR value is more than 3 , then the water is unsuitable for irrigation.

The KR value of this study (Table 4) ranges between 1.3 and 1.55, with a mean value of 1.41. According to the classification of irrigation water based on the KR value, water of KTD lies within the marginal category for irrigation, which indicates an excess level of sodium in the waters.

\subsection{Irrigation Water Quality Index (IWQI)}

IWQI was used and applied to the data of the current study based on the model developed by Meireles et al. (2010). The IWQI was determined through two main steps. The first step: identifying the important physicochemical parameters for irrigation water, including $\mathrm{EC}, \mathrm{Cl}^{-}, \mathrm{Na}^{+}$, and $\mathrm{HCO}_{3}$, where these parameters are required to produce the adopted model [36]. The second step: defining the water quality measurement value $\left(\mathrm{Q}_{\mathrm{i}}\right)$ and aggregation weights $\left(\mathrm{W}_{\mathrm{i}}\right)$ for each parameter [36]. Values of $\left(Q_{i}\right)$ were determined based on the observed value of each parameter and according to irrigation water quality parameters proposed by the University of California Committee of Consultants - UCCC and based on the criteria established by Ayers and Westcot (1999) as shown in (Table 7), water quality parameters were represented by a nondimensional number, where the higher value indicates the better quality of water and vice versa [36].

Values of Qi were calculated using the Equation (5) and based on the tolerance limits given in (Table 7) and the laboratory results of the analyzed parameters [36].

$$
\left.\left.\mathbf{Q}_{\mathrm{i}}=\mathbf{Q}_{\text {imax }}-\mathbf{[}\left(\mathbf{X}_{\mathrm{ij}}-\mathbf{X}_{\mathbf{i n f}}\right) \times \mathbf{Q}_{\mathbf{i a m p}}\right) / \mathbf{X}_{\mathbf{a m p}}\right]
$$

Where, $Q_{i m a x}$ is the maximum value of $Q_{i}$ for the class; $X_{i j}$ is the observed value of each parameter; $X_{\text {inf }}$ is the corresponding value to the lower limit of the class to which the parameter belongs; $Q_{\text {iamp }}$ is class amplitude; $X_{a m p}$ is the class amplitude to which the parameter belongs, to determine the value of $X_{a m p}$ of the final class of each parameter, the uppermost limit was selected to be as the maximum value obtained from the analysis of the water samples [36].

The values of the aggregation weights $\left(\mathrm{W}_{\mathrm{i}}\right)$ for the parameters used in the calculation of IWQI were adopted from [36], where $\left(\mathrm{W}_{\mathrm{i}}\right)$ values were normalized and their sum equals one (Table 8).

The irrigation water quality index (IWQI) was calculated as the following equation.

$$
\mathbf{I W Q I}=\sum_{\mathbf{i}=\mathbf{1}}^{\mathbf{Q}} \mathbf{Q} \mathbf{i} \times \mathbf{W i}
$$

WQI is a dimensionless parameter ranging from 0 to 100; Qi is the quality of the $\mathrm{i}^{\text {th }}$ parameter, a number from 0 to 100 , 
function of the concentration or measurement; $\mathrm{Wi}$ is the normalized weight of the $i^{\text {th }}$ parameter, which is a function of the parameter importance in the irrigation water quality [36].

Table 7. Parameter limiting values for quality measurement (Qi) calculation

\begin{tabular}{|l|l|l|l|l|l|}
\hline Qi & EC $\mu \mathrm{s} / \mathrm{cm}$ & SAR & Na meq $/ 1$ & $\mathrm{Cl}$ meq $/ 1$ & $\mathrm{HCO}_{3}$ meq/l \\
\hline $85-100$ & $200 \leq \mathrm{EC}<750$ & $2 \leq \mathrm{SAR}<3$ & $2 \leq \mathrm{Na}<3$ & $1 \leq \mathrm{Cl}<4$ & $1 \leq \mathrm{HCO}_{3}<1.5$ \\
\hline $60-85$ & $750 \leq \mathrm{EC}<1500$ & $3 \leq \mathrm{SAR}<6$ & $3 \leq \mathrm{Na}<6$ & $4 \leq \mathrm{Cl}<7$ & $1.5 \leq \mathrm{HCO}_{3}<4.5$ \\
\hline $35-60$ & $1500 \leq \mathrm{EC}<3000$ & $6 \leq \mathrm{SAR}<12$ & $6 \leq \mathrm{Na}<9$ & $7 \leq \mathrm{Cl}<10$ & $4.5 \leq \mathrm{HCO}_{3}<8.5$ \\
\hline $0-35$ & EC $<200$ or $\mathrm{EC} \geq 3000$ & $\mathrm{SAR}<2$ or $\mathrm{SAR} \geq 12$ & $\mathrm{Na}<2$ or $\mathrm{Na} \geq 9$ & $\mathrm{Cl}<1$ or $\mathrm{Cl} \geq 10$ & $\mathrm{HCO}_{3}<1$ or $_{\mathrm{HCO}_{3} \geq 8.5}$ \\
\hline
\end{tabular}

Table 8. Weights for the IWQI parameters [36]

\begin{tabular}{|c|c|}
\hline Parameter & Weight (Wi) \\
\hline EC & 0.211 \\
\hline $\mathrm{Na}^{+}$ & 0.204 \\
\hline $\mathrm{HCO}_{3}{ }^{-}$ & 0.202 \\
\hline $\mathrm{Cl}^{-}$ & 0.194 \\
\hline $\mathrm{SAR}$ & 0.189 \\
\hline Total & 1.000 \\
\hline
\end{tabular}

Table 9. Values of IWQI of the surface water samples collected from King Talal Dam

\begin{tabular}{|c|c|}
\hline Site & IWQI \\
\hline Site 1 & 52.83 \\
\hline Site 2 & 53.84 \\
\hline Site 3 & 54.33 \\
\hline Site 4 & 55.02 \\
\hline Site 5 & 55.40 \\
\hline Site 6 & 56.66 \\
\hline Site 7 & 58.54 \\
\hline Min & 52.83 \\
\hline Max & 58.54 \\
\hline Mean & 55.23 \\
\hline
\end{tabular}

IWQI values in the current study ranged between 52.83 and 58.54 (Table 9), based on the classifications of water for irrigation with respect to IWQI values [36] (Table 10), the surface water of KTD is distributed between moderate to high restriction categories for irrigation uses. Therefore, the dam's surface water can be used in soils with moderate to high permeability and with good leaching of salts as well as moderate to high salt tolerant plants should be selected. In addition to that, some kind of treatment is needed to control salinity [36].

The lowest values of IWQI were found in the eastern part of KTD near the Zarqa River (sites 1 and 2), whereas the highest values were observed in the western part of the dam near the outlet point (site 7). The lower water quality in the eastern part of the dam compared to the western part can be attributed to natural, agricultural, industrial and wastewater discharges from the Zarqa River.

\subsection{Comparison of the results of the current study with the related studies}

Many previous studies have been conducted on the waters of King Talal Dam and the Zarqa River, while some of these studies have focused on the chemical and physical properties of the dam's water $[11,17,37,38]$. The comparison of the results of this study with the studies conducted on the water of King Talal dam (Table 11) indicated that the measured parameters $\left(\mathrm{pH}, \mathrm{Ca}^{2+}, \mathrm{Mg}^{2+}, \mathrm{Na}^{+}, \mathrm{K}^{+}, \mathrm{HCO}_{3}^{-}\right.$and $\left.\mathrm{Cl}^{-}\right)$and quality indices (EC, TDS and SAR) in the current study are in agreement with the previously listed results by RSS (20032004).

The values of $\mathrm{pH}, \mathrm{Ca}^{2+}, \mathrm{Mg}^{2+}, \mathrm{Na}^{+}, \mathrm{K}^{+}, \mathrm{Cl}^{-}$and $\mathrm{SAR}$ in this study are within the ranges published by (Al-Taani et al. 2018), whereas TDS values are slightly higher than the ranges published by the same authors. Table (11) showed that the results of $\mathrm{EC}$ and $\mathrm{pH}$ values of the present study are within the ranges documented by Fandi et al. (2009), whereas $\mathrm{Ca}$ and $\mathrm{Na}$ values are lower than their ranges.

By comparing the results of the present study with those reported for Zarqa River water by Hind et al. (2018) (Table 11), all the major cations $\left(\mathrm{Ca}^{2+}, \mathrm{Mg}^{2+}, \mathrm{Na}^{+}\right.$and $\left.\mathrm{K}^{+}\right)$and values of $\mathrm{EC}$ and $\mathrm{MgH}$ in this study are in agreement with their results [39], while the values of the quality indices SAR, Na $\%$ and KR are slightly higher than their results. 
International Journal of Engineering Research and Technology. ISSN 0974-3154, Volume 13, Number 3 (2020), pp. $397-406$

(C) International Research Publication House. https://dx.doi.org/10.37624/IJERT/13.3.2020.397-406

Table 10. Irrigation Water Quality Index Characteristics [36]

\begin{tabular}{|c|c|c|c|}
\hline IWQI & $\begin{array}{l}\text { Water use } \\
\text { restrictions }\end{array}$ & \multicolumn{2}{|l|}{ Recommendation } \\
\hline $85-100$ & $\begin{array}{l}\text { No restriction } \\
(\mathrm{NR})\end{array}$ & $\begin{array}{l}\text { May be used for the majority of soils with low } \\
\text { probability of causing salinity and sodicity problems, } \\
\text { being recommended leaching within irrigation } \\
\text { practices, except for in soils with extremely low } \\
\text { permeability. }\end{array}$ & No toxicity risk for most plants \\
\hline $70-85$ & $\begin{array}{l}\text { Low restriction } \\
(\mathrm{LR})\end{array}$ & $\begin{array}{l}\text { Recommended for use in irrigated soils with light } \\
\text { texture or moderate permeability, being recommended } \\
\text { salt leaching. Soil sodicity in heavy texture soils may } \\
\text { occur, being recommended to avoid its use in soils } \\
\text { with high clay. }\end{array}$ & Avoid salt sensitive plants \\
\hline $55-70$ & $\begin{array}{l}\text { Moderate } \\
\text { restriction (MR) }\end{array}$ & $\begin{array}{l}\text { May be used in soils with moderate to high } \\
\text { permeability values, being suggested moderate } \\
\text { leaching of salts. }\end{array}$ & $\begin{array}{l}\text { Plants with moderate tolerance to salts } \\
\text { may be grown }\end{array}$ \\
\hline $40-55$ & $\begin{array}{l}\text { High restriction } \\
(\mathrm{HR})\end{array}$ & $\begin{array}{l}\text { May be used in soils with high permeability without } \\
\text { compact layers. High frequency irrigation schedule } \\
\text { should be adopted for water with EC above } 2000 \\
\mu \mathrm{s} / \mathrm{cm} \text { and SAR above } 7.0 \text {. }\end{array}$ & $\begin{array}{l}\text { Should be used for irrigation of plants } \\
\text { with moderate to high tolerance to salts } \\
\text { with special salinity control practices, } \\
\text { except water with low } \mathrm{Na}, \mathrm{Cl} \text { and } \mathrm{HCO} 3 \\
\text { values. }\end{array}$ \\
\hline $0-40$ & $\begin{array}{l}\text { Severe } \\
\text { restriction (SR) }\end{array}$ & $\begin{array}{l}\text { Should be avoided its use for irrigation under normal } \\
\text { conditions. In special cases, may be used } \\
\text { occasionally. Water with low salt levels and high SAR } \\
\text { require gypsum application. In high saline content } \\
\text { water soils must have high permeability, and excess } \\
\text { water should be applied to avoid salt accumulation. }\end{array}$ & $\begin{array}{l}\text { Only plants with high salt tolerance, } \\
\text { except for waters with extremely low } \\
\text { values of } \mathrm{Na}, \mathrm{Cl} \text { and } \mathrm{HCO} \text {. }\end{array}$ \\
\hline
\end{tabular}

Table 11. Comparison of the water quality results of this study with related studies on King Talal Dam, and with FAO recommended maximum concentration for irrigation quality and Jordanian allowable limits for the use of reclaimed water for irrigation purposes

\begin{tabular}{|c|c|c|c|c|c|}
\hline Parameter & $\begin{array}{l}\text { This Study } \\
\text { Mean }\end{array}$ & $\begin{array}{c}{[38] .} \\
\text { KTD water }\end{array}$ & $\begin{array}{c}{[11] .} \\
\text { KTD surface water }\end{array}$ & $\begin{array}{c}{[17] .} \\
\text { KTD surface water }\end{array}$ & $\begin{array}{c}\text { [39]. } \\
\text { Zarqa River }\end{array}$ \\
\hline $\mathrm{pH}$ & 8.03 & 7.4-8.7 & $7.76-8.24$ & $8.23-9.79$ & ----- \\
\hline $\mathrm{EC} \mu \mathrm{s} / \mathrm{cm}$ & 1644.2 & $1198-2783$ & 1420 & ----- & $670-2189$ \\
\hline TDS mg/l & 1052.9 & $680-1424$ & ---- & $896-966$ & ----- \\
\hline $\mathrm{Ca} \mathrm{mg/1}$ & 90.0 & $82-163$ & $116-152$ & $90.66-116.91$ & $57-140$ \\
\hline $\mathrm{Mg} \mathrm{mg/l}$ & 30.7 & $19-56$ & $49.2-58.6$ & $30.23-40.33$ & $23-57$ \\
\hline $\mathrm{Na} \mathrm{mg} / \mathrm{l}$ & 226.9 & $92-288$ & $242-263$ & $192.6-260.84$ & $59-269$ \\
\hline $\mathrm{K}$ mg/l & 30.8 & $20-48$ & ----- & $22.17-31.47$ & $4-33$ \\
\hline $\mathrm{HCO} 3 \mathrm{mg} / \mathrm{l}$ & 149.7 & $266-717$ & ----- & $97.6-136.64$ & ----- \\
\hline $\mathrm{Cl} \mathrm{mg/l}$ & 332.4 & $173-452$ & ----- & $320.18-368.02$ & ----- \\
\hline SAR & 5.27 & $2.5-5.5$ & ----- & $4.27-5.42$ & $1.38-5.2$ \\
\hline Mg hazard & 36.0 & ----- & ----- & & $27.2-45.8$ \\
\hline Kelly's Ratio & 1.41 & ----- & ----- & & $0.36-1.39$ \\
\hline $\mathrm{Na} \%$ & 60.3 & ----- & ----- & $54.35-58.53$ & $26.2-58.1$ \\
\hline
\end{tabular}




\section{CONCLUSIONS}

The distribution of the measured parameters in this study showed a more or less similar distribution trend, where the highest concentrations of the parameters were recorded in the eastern part (near Zarqa River flow) and southern part (near Wadi Rmemeen flow) of the dam, whereas the lowest concentrations were recorded in the western part of the dam near the outlet point, which indicate that their sources are similar to some extent and include discharges from industrial and wastewater treatment plants that enter KTD via Zarqa River and Wadi Rmemeen tributaries in addition to the natural discharges from the surrounding catchment areas such as weathering products of rocks and soil erosion.

The values of EC and TDS indicate that the surface water of KTD is fairly saline but still falls within the permissible category for irrigation based on the USDA salinity laboratory classifications of irrigation water. Therefore, the water of KTD can be used for irrigation in soils with good drainage and leaching processes, moreover plants with moderate to high salt tolerance should be selected.

The SAR of KTD indicates that the surface water of the dam is suitable for irrigation, whereas the results of $\mathrm{Na} \%$ showed that the dam's water distributed between permissible to doubtful categories for irrigation. KR values of the present study show that the water of the dam lies within the marginal category for irrigation and indicate an excess level of sodium in the waters. Consequently, the surface water of KTD can be used to irrigate plants that are not sensitive to sodium, and that soils with light texture or good permeability are recommended. However, based on the data of magnesium hazard in this study, the dam's surface water is safe and suitable for irrigation.

The USSL diagram in this study indicates that water of KTD belongs to the category of (C3S2) high salinity hazard and medium sodium hazard, which means that the water of the dam is with the moderate quality for irrigation and can be used to irrigate crops with good salt tolerant and soils with good drainage and good leaching conditions.

The results of the irrigation water quality index (IWQI) show that the water of the dam is distributed between moderate to high restriction categories for irrigation uses. Therefore, the surface water of KTD can be used to irrigate plants with moderate to high salt tolerance and soils with moderate to high permeability and good leaching of salts.

All the analyzed parameters in this study lie within the Jordanian permissible limits for irrigation [20] and within the FAO recommended ranges for irrigation water [19].

Based on the data results of the present study it can be concluded that the water of KTD required special procedures and practices to reduce salinity and sodium hazards.

The application of irrigation water quality index (IWQI) and other indices (EC, SAR, $\mathrm{Na} \%, \mathrm{KR}$ and $\mathrm{MgH}$ ) will be always useful to evaluate the KTD water quality for irrigation purposes, where these indices can be considered as effective tools to provide the decision-makers and related institutions with the observed data in order to be able to understand the status of the water quality of KTD.

\section{ACKNOWLEDGMENTS}

The authors would like to thank the editors and reviewers for their reviewing and commitment to the publication process. Thanks also are extended to the technical staff of King Talal Dam for their help and offer all facilities during sampling and fieldwork

Funding: This research received no external funding.

Conflicts of Interest: The authors declare no conflict of interest.

\section{REFERENCES}

[1] USAID., 2018, "Country Profile: Property Rights and Resource Governance, " Jordan.

[2] MWI., 2016, "Ministry of Water and Irrigation-Jordan: Water Substitution and Reuse Policy, " Jordan.

[3] Khatri, N., and Tyagi, S., 2015, "Influences of natural and anthropogenic factors on surface and groundwater quality in rural and urban areas, "Frontiers in Life Science, 8, pp. 23-39.

[4] Al-Jayyousi, O., 1995, "An analysis of future water policies in Jordan using decision support systems," International Journal of Water Resources Development, 11, pp. 315-30.

[5] Britton, P., and Partners, 1999, "Northern Beaches Stormwater Management Plan, " Northern Beaches Stormwater Management Plan Committee, North Sydney.

[6] Manahan, S., 2004, "Environmental chemistry, " 8th eds, USA, CRC Press.

[7] Thorne, D., and Peterson, H., 1954, "Irrigated Soils, " Constable and Company Limited, London.

[8] RSS., 1984-2005, "Royal Scientific Society reports: Monitoring of the water quality of King Talal Dam," Amman, Jordan.

[9] Salameh, E., and Bannayan, H., 1993, "Water resources of Jordan," Future and Future Potentials, Friedrich Ebert Stiftung, Amman, Jordan.

[10] Hadadin, N., 2015, "Dams in Jordan current and future perspective" Canadian Journal of Pure and Applied Sciences, 9, pp. 3279-3290.

[11] Fandi, K., Qudsieh, I., Muyibi, S., and Massadeh, M., 2009, "Water pollution status assessment of King Talal Dam, " Advances in Environmental Biology, 3(1), pp. 92-100.

[12] Salameh, E., 1991, "Jordan water resources and their future potential," Proceedings of the Symposium, Friedrich Ebert Stiftung, Amman, Jordan.

[13] Soub, F., and Mahasneh, A., 1985, "Chemical Pollution of King Talal Dam Reservoir," Appropriate Waste Management for Developing Countries, Springer, pp. 493-514. 
[14] Salamah E., 1978, "The dangers of eutrophication in the waters of King Talal Dam," Dirasat, 5, pp. 45-58.

[15] Shammout, M.W., and Abualhaija, M. M., 2019, "An analysis of long term yearly water flow trend and its impact on sediment yield in King Talal dam," International Journal of Engineering Research and Technology, 12(12), pp. 3041-3049.

[16] APHA., 1998, "Standard methods for the examination of water and wastewater," American Public Health Association, Washington, DC.

[17] Al-Taani, A. A., El-Radaideh, N.M., and Al Khateeb, W. M., 2018, "Status of water quality in King Talal Reservoir Dam, Jordan," Water Resources,45, pp. 603614.

[18] Abu Hilal, A., and Abualhaija, M., 2010, "Nutrients in water and sediments of King Talal Dam-Jordan," Jordan Journal of Biological Sciences, 147, pp. 1-14.

[19] Ayers, R.S., and Westcot, D.W., 1985, "Water quality for agriculture," FAO Irrigation and Drainage Paper, 29.

[20] JSMO., 2006, "Jordan standards and metrology organization: Standard Specification "WaterReclaimed Domestic Wastewater,"" No. 893/2006, Jordan.

[21] Holden, W.S., 1970, "Water treatment and examination: A successor to the examination of waters and water supplies," 8th eds, Churchill, London, Williams and Wilkins.

[22] Dojlido, J., and Best, G.A., 1993, "Chemistry of water and water pollution," Ellis Horwood Limited.

[23] Stumm, W., and Morgan, J., 1996, "Aquatic Chemistry," 3rd eds, New York, John Wiley and Sons.

[24] Simsek, C., and Gunduz, O., 2007, "IWQ index: A GIS-Integrated technique to assess irrigation water quality," 128 , pp. 277-300.

[25] Mullaney, J.R., Lorenz, D.L., and Arntson, A.D., 2009, "Chloride in groundwater and surface water in areas underlain by the glacial aquifer system, northern United States," US Geological Survey Reston, VA.

[26] Porter, D.O., and Marek, E., 2006, "Irrigation management with saline water," Texas A\&M University, Research and Extension Center.

[27] Ayres, R., and Westcot, D., 1999, "The water quality in agriculture, " 2nd Campina Grande: UFPB, Studies FAO Irrigation and Drainage Paper.
[28] Kundu, S., 2012, "Assessment of surface water quality for drinking and irrigation purposes: a case study of Ghaggar River system surface waters," Bulletin of Environment, Pharmacology \& Life Sciences, 1(2).

[29] Richards, L., 1954, "Diagnosis and improvement of saline and alkali soils," Handbook No. 60. US Department of Agriculture, Washington, DC.

[30] Fipps, G., 2003, "Irrigation water quality standards and salinity management strategies," Texas FARMER Collection.

[31] Wilcox, L., 1948, "The quality of water for agricultural use," US Department of Agriculture, Washington, DC, Technical Bulletin.

[32] Wilcox, L., 1955, "Classification and use of irrigation water," US Department of Agriculture, Washington, DC, 19.

[33] Szabolcs, I., and Darab, C., 1964, "The influence of irrigation water of high sodium carbonate content of soils," Proceedings of 8th international congress of ISSS, Trans, pp. 803-812.

[34] Kelley, W., 1963, "Use of saline irrigation water," Soil science, (95)6, pp. 385-391.

[35] Kelley, W., 1957, "Adsorbed Na+, Cation-Exchange Capacity and Percentage Na+ Saturation of Alkali Soils," Soil Science, (84)6, pp. 473-478.

[36] Meireles, A.C.M., Andrade, E.M.D., Chaves, L.C.G., Frischkorn, H., and Crisostomo, L.A., 2010, "A new proposal of the classification of irrigation water," Revista Ciência Agronômica, (41)3, pp. 349-357.

[37] Abualhaija, M.M., Shammout, M.W., Mohammad, A.H., and Abu-Hilal, A.H., 2019, "Heavy Metals in water and sediments of King talal Dam the largest Man-Made water Body in Jordan," Water and Energy International, (62)5, pp. 49-62.

[38] RSS., 2003-2004, "Royal Scientific Society reports: Monitoring of the water quality of King Talal Dam," Amman, Jordan.

[39] Alsharifa-Hind, M., Abualhaija, M.M., and Shammout M.W., 2018, "Chemical Indices of Water Quality in the Zarqa River-Jordan: Concentrations of Major Cations and Water Suitability for Irrigation," International Journal of Applied Engineering Research, (13)1, pp. 697-706 